\title{
EFEKTIVITAS MODEL PEMBELAJARAN INQUIRY UNTUK MENINGKATKAN PENALARAN MATEMATIS SISWA PADA MATERI PELUANG
}

\author{
Sandi Triatma ${ }^{1}$, Citra Utami ${ }^{2}$, Rika Wahyuni ${ }^{3}$ \\ STKIP Singkawang, Singkawang, Indonesia \\ sanditriatma11@gmail.com ${ }^{1}$, citrautami1990@gmail.com ${ }^{2}$, rikawahyuni33@yahoo.com ${ }^{3}$
}

\author{
Keywords : \\ Pembelajaran Inquiry, Penalaran \\ Matematis, Peluang
}

\begin{abstract}
Penelitian ini bertujuan untuk mengetahui efektivitas model pembelajaran Inquiry untuk meningkatkan kemampuan penalaran matematis siswa. Jenis penelitian ini adalah Quasi Experimental Design dengan desain penelitian Non Equivalen Control Group Design. Populasi dalam penelitian ini adalah seluruh siswa kelas IX SMP Barito Singkawang sebanyak 3 kelas yaitu kelas IXA, IXB, dan IXC. Pengambilan sampel dalam penelitian ini menggunakan sampling purposive yaitu kelas IXA kelas sebagai kelas eksperimen dan kelas IXC sebahgai kelas kontrol. Instrumen yang digunakan dalam penelitian ini adalah tes kemampuan penalaran matematis, dan angket motivasi siswa. Sebelum digunakan instrumen terlebih dahulu diuji validitasnya dengan ahli. Hasil penelitian menunjukan : 1) kemampuan penalaran matematis siswa mencapai kriteria ketuntasan minimum $(K K M=70)$ secara individu dan klasikal yaitu sebesar 77,38 dan ketuntasan klasikal melampaui $75 \%$; 2) Terdapat perbedaan peningkatan kemampuan penalaran matematis siswa dengan menggunakan model pembelajaran Inquiry. 3) Motivasi belajar siswa kelas IX SMP Barito Singkawang tinggi pada materi peluang setelah diterapkan model pembelajaran Inquiry sebesar 128,31 dengan kategori sangat tinggi.penelitian menunjukan bahwa persentase siswa dalam memecahkan masalah geometri berdasarkan teori Van Hiele masih berada pada kategori rendah. Jadi dari hasil penelitian didapat bahwa siswa yang memiliki kemampuan koneksi berdasarkan tingkat berpikir level 2 berada di kategori sedang sedangkan kemampuan koneksi dengan tingkat berpikir level 1 dan level 0 berada pada kategori rendah.
\end{abstract}




\section{PENDAHULUAN}

Kemampuan penalaran matematis sangat bergantung dengan adanya masalah yang ada di dalam matematika. Menurut National Council of Teacher of Mathematics (NCTM, 2000:53) penalaran matematis berarti terlibat dalam tugas yang solusinya tidak diketahui sebelumnya, kemampuan penalaran matematika merupakan salah satu tujuan dari pembelajaran matematika. Penalaran matematika yang mencakup kemampuan untuk berpikir secara logis dan sistematis merupakan ranah kognitif matematik yang paling tinggi. Selain itu, pentingnya penalaran matematis dalam pembelajaran matematika, maka pembelajaran matematika perlu direncanakan sedemikian rupa sehingga pada akhir pembelajaran, siswa dapat melakukan penalaran mengenai ide-ide matematis (Gusnarsi dkk, 2017). Namun pada kenyataan yang terjadi, kemampuan penalaran matematis siswa SMPS Barito Singkawang masih rendah. Hal tersebut dibuktikan dengan hasil wawancara dengan salah satu guru bidang studi mata pelajaran matematika kelas IX SMPS Barito Singkawang, dijelaskan bahwa proses pembelajaran matematika di kelas umumnya masih menggunakan model pembelajaran ekspositori yang didominasi oleh metode ceramah, sehingga siswa kurang optimal didorong untuk mengembangkan kemampuan berpikir. Pembelajaran matematika cenderung Teacher Centered sehingga siswa menjadi pasif. Kurang adanya kesadaran dan keinginan dari diri siswa untuk belajar, kurangnya dorongan untuk menumbuhkan minat belajar, serta kurangnya kemampuan penalaran matematis siswa sehingga menjadi penyebab dari rendahnya nilai hasil belajar masih di bawah KKM dan kurangnya motivasi belajar siswa dalam proses belajar. Kemampuan penalaran matematis siswa Indonesia dinyatakan rendah, hal ini diperkuat oleh penelitian yang dilakukan oleh Rimbayanto (2015) yang menunjukan bahwa kemampuan penalaran matematis siswa SMP Negeri 2 grobogan masih rendah. Berdasarkan hasil penelitian Rimbayanto menunjukkan kemampuan menalar matematika siswa dapat dilihat dari indikator 1) menggambarkan masalah secara simbolis dengan memanipulasi simbol-simbol sebanyak 10 siswa $(31,25 \%)$ dan 2$)$ menarik kesimpulan dari permasalahan matematika (berpendapat, menyimpulkan) sebanyak 2 siswa $(6,25 \%)$.

Selain dibuktikan dengan hasil wawancara, rendahnya kemampuan pemahaman konsep matematis siswa SMPS Barito Singkawang juga dibuktikan dengan hasil prariset yang telah dilakukan yang terdiri dari indikator-indikator kemampuan penalaran matematis, yaitu: (1) mengajukan dugaan; (2) melakukan maipulasi matematika; dan (3) menentukan pola atau sifat dari gejala matematis untuk membuat generalisasi dengan tepat. Soal prariset diberikan kepada 26 orang siswa dan soal tersebut diberikan sebanyak 3 soal. Hasil dari soal prariset tersebut yaitu untuk nomor 1 hanya 9 orang siswa dengan persentase $34,48 \%$ yang menjawab soal dengan benar, sedangkan terdapat 17 orang siswa dengan persentase sebesar $65,52 \%$ yang tidak menjawab soal. Sedangkan untuk soal nomor 2 , hasil yang diperoleh hanya terdapat 6 orang siswa saja dengan persentase $24,14 \%$ yang benar dalam menjawab soal, sedangkan terdapat 17 orang siswa dengan persentase sebesar $75,86 \%$ yang tidak menjawab soal. Sedangkan untuk soal nomor 3, hasil yang diperoleh hanya terdapat 3 orang siswa saja dengan persentase $10,34 \%$ yang benar dalam menjawab soal, sedangkan terdapat 23 orang siswa dengan persentase sebesar $89,66 \%$ yang tidak menjawab soal. Selain dengan hasil prariset, penalaran matematis siswa kelas IX SMPS Barito Singkawang terhadap pelajaran matematika juga masih rendah. Dalam kegiatan pembelajaran yang masih cenderung Teacher Centered sehingga siswa masih menjadi pasif, menyebabkan siswa kesulitan dalam menyelesaikan suatu masalah sehingga banyak siswa yang mendapat nilai pada mata pelajaran matematika belum mencapai kriteria ketuntasan minimal (KKM) yaitu 70.

Satu di antara materi pelajaran matematika yang akan diteliti yaitu materi peluang di kelas IX karena dalam materi ini masih banyak siswa yang mendapat nilai yang belum mencapai Kriteria Ketuntasan Minimal (KKM). Kelemahan penalaran matematis dalam hal ini siswa belum bisa mengajukan dugaan dan memberikan alasan dari jawaban yang kurang tepat, menjawab pertanyaan secara langsung tanpa addanya melakukan manipulasi matematika, serta keliru dalam menentukan pola atau sifatdari gejala matematis dengan membuata generalisasi. 
Untuk mengatasi permasalahan di atas diperlukan suatu tindakan untuk mengatasinya. Tindakan yang dapat dilakukan antara lain adalah dengan menerapkan berbagai model pembelajaran yang sesuai dengan tujuan yang ingin dicapai. Suatu model pembelajaran efektif yang dapat diterapkan untuk menumbuhkan kemampuan penalaran matematis siswa salah satunya adalah pembelajaran dengan metode Inquiry. Pembelajaran dengan model Inquiry ini berpusat pada siswa sehingga siswa benarbenar terlibat secara aktif dalam proses pembelajaran. Sutrisno (2008) mengungkapkan bahwa model pembelajaran Inquiry berupaya menanamkan dasar-dasar berpikir ilmiah pada diri siswa, sehingga dalam proses pembelajaran ini siswa lebih banyak belajar sendiri, mengembangkan kreativitas dalam bernalar. Siswa benar-benar ditempatkan sebagai subjek yang belajar. Peranan guru dalam pembelajaran dengan model Inquiry adalah sebagai pembimbing dan fasilitator. Keunggulan menggunakan model pembelajaran inkuiri ini dapat mengatasi pembelajaran yang cenderung pasif, meningkatkan kerja keras kelompok antar siswa yang satu dengan yang lain, proses membaca, mengamati, dan bekerja sama Buyung, B., \& Dwijanto, D. (2017). Penelitian yang dilakukan oleh sudiasa (2010) juga menunjukan bahwa hasil rata-rata siswa menggunakan model pembelajaran inkuiri adalah 86,90 lebih baik dari rata-rata siswa mengunakan model konvensional yaitu 73,81. Berdasarkan latar belakang tersebut dapat disusun tujuan penelitian ini sebagai berikut: (1) Untuk mengetahui kemampuan penalaran matematis siswa mencpaia kriteria ketuntasan minimum secara individu maupun klasikal; (2) Untuk mengetahui perbedaan peningkatan kemampuan penalaran matematis siswa pada materi peluang dengan menggunakan model pembelajaran Inquiry dan pembelajaran langsung; dan (3) Untuk mengetahui motivasi belajar siswa setelah diterapkan pembelajaran Inquiry terhadap kemampuan penalaran matematis siswa kelas IX SMPS Barito Singkawang pada materi peluang.

\section{METODE}

Penelitian ini menggunakan metode penelitian eksperimen. Metode penelitian eksperimen adalah metode penelitian yang digunakan untuk mencari pengaruh perlakuan tertentu terhadap yang lain dalam kondisi yang terkendalikan (Sugiyono, 2011; 107). Desain penelitian ini menggunakan dua kelas yaitu kelas eksperimen dengan menggunakan model pembelajaran Inquiry dan kelas kontrol dengan menggunakan model pembelajaran konvensional. Adapun desain yang digunakan adalah Quasi Experimental Design. Tempat penelitian dilaksanakan di SMPS Barito Singkawang, dan waktu penelitian yang digunakan berlangsung selama tujuh hari. Populasi dalam penelitian ini yaitu seluruh siswa kelas IX SMPS Barito Singkawang yang terdiri atas kelas IX A, kelas IX B, dan kelas IX C. Teknik pengambilan sampel penelitian yang digunakan dalam penelitian ini adalah dengan menggunakan teknik Sampling Purposive, yaitu teknik penentuan sampel dengan pertimbangan tertentu (Sugiyono, 2014:85). Pada model pengambilan sampel dalam penelitian ini yaitu menggunakan model pengambilan purposive sampling yang dilakukan atas pertimbangan dan persetujuan antara penulis dengan guru matematika kelas IX SMPS Barito Singkawang. Jadi, sampel pada penelitian ini yaitu kelas IX A sebagai kelas eksperimen yang berjumlah 26 orang siswa dan kelas IX B sebagai kelas kontrol yang berjumlah 26 orang siswa. Variabel dalam penelitian ini adalah variabel bebas yaitu model pembelajaran inquiry, dan variabel terikat yaitu kemampuan penalaran matematis siswa, ketuntasan hasil belajar siswa dan motivasi belajar siswa, guru yang mengajar yaitu peneliti, dan materi pembelajaran yaitu materi peluang. Data yang dikumpulkan dalam penelitian ini berasal dari lembar keterlaksanaan pembelajaran yang dilakukan oleh teman sejawat untuk memperoleh data keterlaksanaan pembelajaran dengan menggunakan model pembelajaran inquiry, dan tes tertulis untuk memperoleh data tentang nilai kemampuan pemahaman konsep matematis siswa yang dilaksanakan setelah proses pembelajaran, serta pemberian angket respon untuk memperoleh data tentang respon siswa setelah proses pembelajaran. Sebelum melakukan penelitian, maka dilakukan terlebih dahulu uji validitas, uji reliabilitas, tingkat kesukaran, dan daya pembeda.

Kemudian teknik analisis data yang digunakan dalam penelitian ini adalah sebagai berikut. (1) Untuk menjawab sub masalah 1 yaitu mengetahui kriteria ketuntasan dalam kemampuan penalaran matematis 
siswa secara individu maupun klasikal pada materi peluang kelas IX SMPS Barito Singkawang maka digunakan rumus uji-t.. (2) Untuk menjawab sub masalah 2 yaitu mengetahui kemampuan penalaran matematis siswa dengan menggunakan model pembelajaran Inquiry dan model pembelajaran konvensional pada materi peluang kelas IX SMPS Barito Singkawang maka digunakan rumus N-gain. (3) Untuk menjawab sub masalah 3 yaitu untuk mengetahui motivasi belajar siswa digunakan rumus presentase motivasi belajar siswa.

\section{HASIL DAN PEMBAHASAN}

Data yang disajikan dalam penelitian ini adalah data yang diperoleh dari hasil jawaban soal posttest yang diberikan kepada kelas eksperimen dan kelas kontrol. Adapun soal posttest yang diberikan berbentuk tes kemampuan penalaran matematis sebanyak 3 soal dengan indikator-indikator sebagai berikut yaitu: (1) mengajukan dugaan; (2) melakukan maipulasi matematika; dan (3) menentukan pola atau sifat dari gejala matematis untuk membuat generalisasi dengan tepat. Adapun rekapitulasi ratarata nilai posttest kemampuan penalaran matematis siswa kelas eksperimen dan kelas kontrol ditinjau dari keseluruhan data disajikan pada Tabel 4 berikut.

Tabel 4. Rekapitulasi Nilai Rata-rata Posttest Kemampuan Penalaran Matematis Siswa

\begin{tabular}{ccc}
\hline Keterangan & Kelas Eksperimen & Kelas Kontrol \\
\hline Rata-rata & 77,38 & 50,62 \\
Standar Deviasi & 7,17 & 11,48 \\
\hline
\end{tabular}

Berdasarkan Tabel 4, analisis data rata-rata posttest kemampuan penalaran matematis siswa kelas eksperimen lebih tinggi yaitu sebesar 77,38 dibandingkan rata-rata kemampuan pemahaman konsep matematis siswa kelas kontrol yaitu sebesar 50,62. Selain itu, berdasarkan uji hipotesis menunjukkan bahwa Ho ditolak dan Ha diterima sehingga terdapat perbedaan yang signifikan antara kelas eksperimen yang menggunakan model Inquiry dan kelas kontrol yang menggunakan model pembelajaran langsung yaitu kemampuan penalaran matematis siswa kelas ekperimen lebih tinggi dibanding kemampuan penalaran matematis siswa kelas kontrol.

Selanjutnya untuk mengetahui motivasi siswa terhadap model pembelajaran inquiry terhadap kemampuan penalaran matematis siswa dengan menggunakan memberikan angket dan pemberian skor pada angket. Angket ini berisi 30 pernyataan yang terdiri dari 14 pernyataan positif dan 16 pernyataan negatif, siswa hanya perlu memberi tanda checklist $(\sqrt{ })$ pada kolom yang tersedia sebanyak 5 buah. Keterangan untuk masing-masing kolom tersebut yaitu Sangat Setuju (SS), Setuju (S), Ragu-ragu (R), Kurang Setuju (KS), dan Tidak Setuju (TS). Adapun rekapitulasi hasil perhitungan dengan penskoran dapat dilihat pada Tabel 9 berikut ini.

Tabel 9. Rekapitulasi Hasil Perhitungan skor angket motivasi Siswa Kelas Eksperimen

\begin{tabular}{cc}
\hline Keterangan & Skor \\
\hline Rata - Rata & 128,31 \\
\hline Kriteria & Sangat Tinggi \\
\hline
\end{tabular}

Berdasarkan perhitungan skor angket motivasi siswa pada Tabel 9 di atas, maka diperoleh nilai skor yaitu 128,31 dengan kriteria sangat tinggi. Hal ini dapat disimpulkan bahwa motivasi belajar siswa sangat tinggi dengan penerapan model pembelajaran inquiry terhadap penalaran matematis siswa.

Berdasarkan analisis kemampuan penalaran matematis, siswa yang diberikan perlakuan dengan model pembelajaran Inquiry dapat meningkatkan kemampuan penalaran matematis siswa. Hal ini dapat dilihat dari hasil tes kemampuan penalaran matematis siswa yang menunjukan bahwa peningkatan kemampuan penalaran matematis siswa yang diberikan perlakuan dengan menggunakan model 
pembelajaran Inquiry lebih tinggi dari pada siswa tidak diberikan perlakuan dengan menggunakan model pembelajaran Inquiry.

Faktor yang memengaruhi kemampuan penalaran matematis siswa adalah penerapan model pembelajaran inquiry dengan rangkaian kegiatan pembelajaran yang menarik, yaitu siswa dapat memahami permasalahan, merumuskan jawaban dari permasalahan, dan siswa mencari dan menemukan jawaban dengan menghubungkan pengetahuan konsep dasar siswa itu sendiri terkait dengan materi pembelajaran sehingga kemampuan pemahaman konsep matematis siswa menjadi lebih baik. Hal ini juga sejalan dengan penelitian yang dilakukan oleh Mariyam (2016) Hasil penelitian menunjukkan bahwa terdapat peningkatan kemampuan penalaran matematis siswa melalui Problem Centered Learning pada materi peluang.

Dari uraian tersebut Berdasarkan rata-rata peningkatan kemampuan penalaran matematis siswa secara keseuruhan diketahui nilai rata-rata $\mathrm{N}$-gain kelas eksperimen sebesar 0,59 dengan kategori sedang dan kelas kontrol sebesar 0,48 dengan kategori sedang. Oleh karena itu, selanjutnya dilakukan uji perbedaan rata-rata peningkatan kemampuan penalaran matematis siswa dengan menggunakan model pembelajaran Inquiry dapat dilihat dari keterkaitan model pembelajaran Inquiry dengan kemampuan penalaran matematis. Dimana keterkaitannya adalah dimana siswa dapat menemukan sendiri dalam menyelesaikan suatu masalah dengan bernalar. Hal ini sejalan dengan teori Gagne menyatakan bahwa tipe belajar paling tinggi adalah kemampuan siswa dalam pemecahan masalah, sehingga model pembelajaran Inquiry yang menekankan pada kemampuan penalaran matematis dapat meningkatkan kemampuan penalaran matematis siswa.

Selanjutnya dengan perhitungan uji hipotesis menggunakan uji-t independen sampel t-test dengan taraf signifikan 5\% diperoleh nilai t_hitung lebih kecil sama dengan dari nilai t_tabel atau 2,297 > 2,060. Berarti H_o ditolak dan H_a diterima, artinya terdapat perbedaan peningkatan kemampuan penalaran matematis siswa yang signifikan antara yang diberikan model pembelajaran Inquiry dan pembelajaran konvensional pada materi peluang kelas IX SMP. Hal ini relevan dengan hasil penelitian Rimbayanto (2014) dengan menerapkan model Inquiry dapat meningkatkan kemampuan menalar matematika siswa daripada yang menggunakan model pembelajaran konvensional.

Berdasarkan hasil angket motivasi siswa dengan penerapan model pembelajaran Inquiry pada kelas eksperimen diperoleh nilai 128, 31 dengan skala penskoran $120<\mathrm{X} \leq 150$ dapat disimpulkan motivasi belajar siswa dengan penerapan model pembelajaran inquiry dengan kriteria sangat tinggi. Hal ini juga sejalan dengan penelitian yang dilakukan oleh Yanda (2019) Hasil penelitian menunjukkan bahwa terjadi peningkatan motivasi belajar matematika siswa dengan merapkan model pembelajaran Inquiry.

\section{KESIMPULAN DAN SARAN}

Berdasarkan hasil pengolahan data penelitian yang dilakukan, secara umum dapat disimpulkan bahwa model pembelajaran Inquiry efektif terhadap kemampuan penalaran matematis siswa pada materi peluang. Sebagai fokus penelitian agar sejalan dengan sub-sub masalah penelitian yang telah ditentukan, hasil dari sub-sub masalah penelitian tersebut sebagai berikut. : 1) kemampuan penalaran matematis siswa mencapai kriteria ketuntasan minimum $(\mathrm{KKM}=70)$ secara individu dan klasikal yaitu sebesar 77,38 dan ketuntasan klasikal melampaui 75\%;2) Terdapat perbedaan peningkatan kemampuan penalaran matematis siswa dengan menggunakan model pembelajaran Inquiry. Hal ini ditunjukan oleh hasil uji N-Gain pada kelas eksperimen sebesar 0,59 dan kelas kontrol sebesar 0,48, dan Uji t yang menunjukan bahwa nilai thitung 2,297 dan ttabel 2,060 yaitu 2,297 > 2,060;3) Motivasi belajar siswa kelas IX SMP Barito Singkawang tinggi pada materi peluang setelah diterapkan model pembelajaran Inquiry sebesar 128,31 dengan katagori sangat tinggi. 
Saran yang dapat disampaikan diantaranya yaitu dalam proses pembelajaran berlangsung, diharapkan siswa dapat mengikuti langkah - langkah sesuai prosedur yang telah disepakati bersama dalam tahap perencanaan pembelajaran dengan model pembelajaran Inquiry. Pada tahap mempresentasikan hasil diskusi diupayakan agar siswa yang lainnya dapat memperhatikan sehingga kegiatan presentasi dapat berjalan dengan baik dan mendapatkan hasil yang maksimal. Pada proses pembelajaran guru diharapkan dapat mengkondisikan kelas secara kondusif agar pembelajaran yang diberikan kepada siswa dapat dipahami dengan baik. Diharapkan kepada peneliti selanjutnya untuk dapat melakukan penelitian lanjutan dengan menyempurnakan kekurangan-kekurangan yang ada, karena penelitian ini masih jauh dari kesempurnaan.

\section{DAFTAR PUSTAKA}

Buyung, B., \& Dwijanto, D. (2017). Analisis Kemampuan Literasi Matematis melalui Pembelajaran Inkuiri dengan Strategi Scaffolding. Unnes Journal of Mathematics Education Research, 6(1), 112-119.

Gusnarsi, Desi, Citra Utami, and Rika Wahyuni. "Pengaruh Model Pembelajaran Realistic Mathematics Education (RME) Terhadap Kemampuan Penalaran Matematis Siswa Pada Materi Lingkaran Kelas VIII." JPMI (Jurnal Pendidikan Matematika Indonesia) 2.1 (2017): 32-36.

Mariyam, Mariyam, and Rika Wahyuni. "Mengembangkan Kemampuan Penalaran Matematis Siswa Melalui Problem Centered Learning Pada Materi Peluang (Studi Eksperimen Di Kelas VIII SMP N 6 Singkawang)." JPMI (Jurnal Pendidikan Matematika Indonesia) 1.2 (2016): 74-80.

National Countil of Teacher of Mathematics (NCTM). (2000). Principles standards for school mathematics. Virginia. Reston.

Rimbayanto, Alek (2015). Peningkatan Kemampuan Menalar Dan Memecahkan Masalah Matematikadengan Model Inquiry Learning Berbasis Group Investigation Pada Siswakelas VII Semester 1 SMP Negeri 2 Grobogan Tahun 2014/2015. Skripsi: Universitas Muhammadiyah Surakartat.

Rimbayanto, Alek. Peningkatan Kemampuan Menalar Dan Memecahkan Masalah Matematikadengan Model Inquiry Learning Berbasis Group Investigation Pada Siswakelas VII Semester 1 SMP Negeri 2 Grobogan Tahun 2014/2015. Diss. Universitas Muhammadiyah Surakarta, 2015.

Sudiasa, I. Wayan. "Pengaruh Model Pembelajaran Inkuiri Dan Kemampuan Numerik Terhadap Hasil Belajar Matematika." Jurnal Pendidikan dan Pengajaran 45.3 (2012).

Sugiyono. (2011).Metode penelitian kuantitaif kualitatif dan R \& D. Bandung : Alfabeta

Sugiyono. (2014). Metode penelitian kuantitatif kualitatif dan R\&D. Bandung: Alfabeta.

Sutrisno,dkk (2008). Pengembangan Pembelajaran IPA SD.Jakarta: Direktorat Jendral Pendidikan Tinggi Departemen Pendidikan Nasional

Yanda, Ketren Ocmita, Jumroh Jumroh, and Dina Octaria. "Pengaruh Model Pembelajaran Inkuiri Terhadap Kemampuan Pemahaman Konsep Ditinjau Dari Motivasi Belajar Siswa." JURNAL INDIKTIKA 2.1 (2019): 58-67. 